\title{
Characteristics of Torrefaction with Water Hyacinth
}

\author{
Dae Bin Song*, Min Soo Kim \\ Department of Bio-Industrial Machinery Engineering, Gyeongsang National University \\ (Institute of Agric. \& Life Sci.), 501 Jinju-daero, Jinju, Korea
}

Received: June $30^{\text {th }}, 2013$; Revised: August $2^{\text {th }}, 2013$; Accepted: August $14^{\text {th }}, 2013$

\section{Abstract}

Purpose: This study explored the factors influencing heating value in the process of torrefaction of water hyacinth. Methods: Torrefaction was applied with three temperature settings $\left(200,300,400^{\circ} \mathrm{C}\right)$ and three time settings $(1,2,3 \mathrm{~h})$ using small electric heaters (11.3 $\mathrm{L}$ of holding volume). This study investigated the heating values with the washing process and process factors influenced the torrefaction. In addition, this study compared the heating values in washed and unwashed samples and suggested the optimal conditions for increasing heating value. Results: Torrefaction increased the heating value by $8.18 \sim 30.04 \%$. Comparing heating values of each condition, the optimal temperature for torrefaction was $300^{\circ} \mathrm{C}$ and holding time was 1 hour. The washing process increased the heating value by $19 \sim 27 \%$. The heating value of the sample treated at $300^{\circ} \mathrm{C}$ for three hours was $4310.80 \mathrm{kcal} / \mathrm{kg}$, which was greater than the first class wood pellet of 4300 $\mathrm{kcal} / \mathrm{kg}$. Conclusions: This study proved that the torrefaction and washing process increased the heating value of water hyacinth. Therefore, water hyacinth is expected to be an eco-friendly biomass which substitutes for wood pellet.

Keywords: Ash content, Biomass, Heating value, Torrefaction, Water hyacinth

\section{Introduction}

As worldwide concerns about global warming due to the emissions of $\mathrm{CO}_{2}$ and other greenhouse gas have increased, interest in using biomass for energy is on the rise. Presently, biomass is gaining importance worldwide as a renewable energy resource. Because biomass is considered carbon neutral, it can significantly reduce net carbon emissions and negative environmental impacts when it replaces coal or other fossil fuels (Tumuluru et al., 2012).

Torrefaction is a thermochemical pretreatment process at $200 \sim 300^{\circ} \mathrm{C}$ in an inert condition which transforms biomass into a relatively superior handling, milling, co-firing and clean renewable energy into solid biofuel (Acharya et al., 2012). Patel et al. (2011) reported that the gross heating value of cotton stalk, prosopis and sugarcane

\footnotetext{
*Comesponding author: Dae Bin Song

Tel: +82-55-772-1895; Fax: +82-55-772-1899

E-mail: dbsong@gnu.ac.kr
}

bagasse increased by $21 \sim 41 \%$ after the treatment of 1 hour torrefaction at $300^{\circ} \mathrm{C}$. Pimchuai et al. (2010) found out that higher heating value of rice husks, sawdust, peanut husks, bagasse and water hyacinth increased by 9 $\sim 16.6 \%$ after the treatment of three time settings $(1,1.5$, $2 \mathrm{~h}$ ) and temperature $\left(250,270,300^{\circ} \mathrm{C}\right)$. Lee et al. (2012) showed that the highest heating value $(5,132 \mathrm{kcal} / \mathrm{kg})$ of mixed softwood chip increased by $13 \%$ after the treatment of 30 minutes at $280^{\circ} \mathrm{C}$.

By the introduction of RPS (Renewable Portfolio Standards) which is a regulation that requires the increased production of energy from renewable energy sources, the amount of electricity from renewable energies reached $2 \%$ of the total power generation in 2012 and will be $10 \%$ by 2022 in Korea. Thus, the interest in using biomass for energy has increased with the practice of 2012 greenhouse gas reduction target setting program (Park et al., 2012). However, using biomass should guarantee the heating value of fossil fuel and mass production at a low cost.

Many studies on biomass especially, research on 
developing wood boilers for agricultural facilities have been funded by government because the wood powder can be obtained easily and its heating value is high enough to substitute coal. Problems in raw material prices, however, due to the limited wood resources and extra cost for powdering wood have hindered the studies. Furthermore, the research on wood boilers could not apply to the agricultural facilities because the combustion gas emitted from the boiler caused problems in operating the boiler.

Water hyacinth (Eichhornia crassipes) is a perennial aquatic plant native to tropical and sub-tropical South America, and it takes between 6 and 28 days to double in weight, and between 4 and 58 days to double in numbers; 2 million plants per ha that weigh $270 \sim 400$ tons (Gopal, 1987; Epstein, 1998). The plant grows so fast without any additional supply of nourishment at $20^{\circ} \mathrm{C}$ water, so it can be grown at the reservoirs from April to October in Korea. Thus, the water hyacinth can be a good substitute of wood in terms of price if the heating value is improved by torrefaction.

The purpose of this study is to investigate the factors influencing heating value in the process of torrefaction of water hyacinth.

\section{Materials and Methods}

\section{Torrefaction unit}

Torrefaction unit was composed of a sample chamber, electric heaters, an argon gas inlet, a sensor for measuring oxygen concentration, a cooling fan, a thermo couple, a temperature control unit as in Figure 1. The chamber was

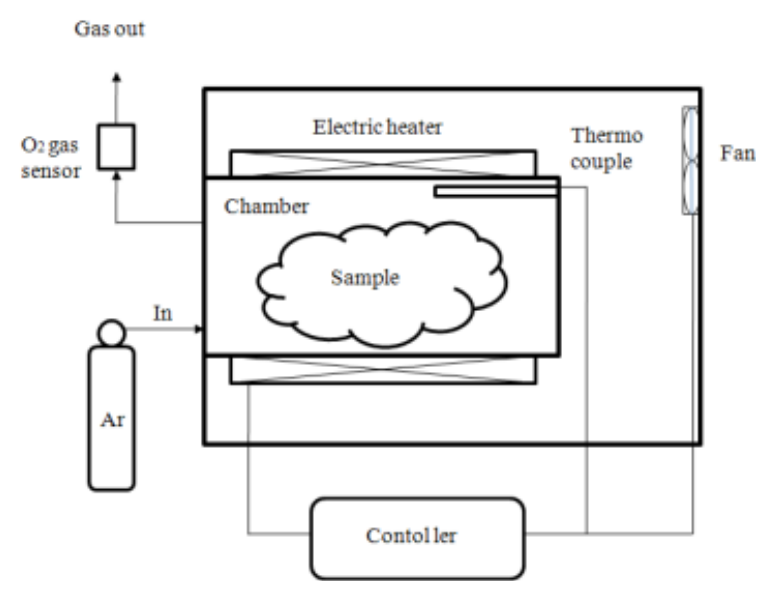

Figure 1. Schemetic diagram of the torrefaction unit. a cylindrical $(11.3 \ell, \varnothing 0.16 \times 0.56 \mathrm{~m})$, and the electric heaters were attached outside the chamber. The maximum temperature of the heater was $1000^{\circ} \mathrm{C}$, and the temperature inside the chamber was maintained by the controlling thermo couple, cooling fan, and on and off of the temperature control unit. Argon gas was supplied after the sample was placed in the chamber, which was to prevent ignition of the sample at high temperature. During the process of torrefaction oxygen concentration inside the chamber was checked with the sensor attached at the outlet.

\section{Materials}

The water hyacinth imported from Thailand in 2012 was used for the experiments about comparison of heating values with the torrefaction and changes of heating value with temperature change. And the plants grown at the Gumho reservoir, Jinju, Gyeongnam province in 2012 were used for the experiments about comparison of heating values with washing process. The plants were dried by hot air so that the moisture content was maintained about $20 \%$ (wb).

\section{Torrefaction}

The water hyacinth rises above the surface of the water, so it has impurities such as mud on the leaves. For this reason, the washing process and each part of the plant can influence the heating value. The unwashed plants were cut by $15 \mathrm{~mm}$ and experimented with three different temperature settings $\left(200,300,400^{\circ} \mathrm{C}\right)$, and three different time settings $(1,2,3 \mathrm{~h})$. After the sample was placed in the chamber, Argon gas was injected to remove oxygen in it.

The torrefied samples were powdered, and the heating value was measured with $1.0 \mathrm{~g}$ of the powder using the Calorimeter (Parr 6400, Parr Instrument Company, USA). The amount of ashes was measured following the method suggested by Korean Forest Service (2009). The experiments were repeated three times, and the average value was used for the result.

\section{Results and Discussion}

\section{The effect of torrefaction}

Table 1 shows the heating value and ash content of two different types of samples (raw sample and torrefied sample). The values of raw sample represent the average 
Song et al. Characteristics of Torrefaction with Water Hyacinth

Journal of Biosystems Engineering • Vol. 38, No. 3, 2013 • www.jbeng.org

Table 1. Heating value and ash content of two different samples (raw sample and torrefied sample)

\begin{tabular}{ccc} 
Experimental condition & Heating value $(\mathrm{kcal} / \mathrm{kg})$ & Ash content $(\%)$ \\
Raw & $3053.03 \pm 55.26$ & $10.87 \pm 0.21$ \\
\hline $200^{\circ} \mathrm{C}(1,2,3 \mathrm{~h}$ of holding time $)$ & $3302.73 \pm 83.30$ & $23.32 \pm 0.95$ \\
$300^{\circ} \mathrm{C}(1,2,3 \mathrm{~h}$ of holding time) & $3961.02 \pm 121.57$ & $35.65 \pm 1.41$ \\
$400^{\circ} \mathrm{C}(1,2,3 \mathrm{~h}$ of holding time $)$ & $3970.16 \pm 142.01$ & $39.65 \pm 1.57$ \\
\hline
\end{tabular}

heating values and ash contents of three samples. The values of torrefied sample represent the average heating values and ash contents of nine samples at three different time settings. Therefore, the standard deviation of torrefied sample was larger than the raw sample. Torrefaction improved the heating value; the torrefied samples increased compared to the raw sample by $8.18 \%$ at $200^{\circ} \mathrm{C}, 29.74 \%$ at $300^{\circ} \mathrm{C}$, and $30.04 \%$ at $400^{\circ} \mathrm{C}$. However, the maximum heating value of the sample was $3970.16 \mathrm{kcal} / \mathrm{kg}$, which is smaller than the first class wood pellet of $4300 \mathrm{kcal} / \mathrm{kg}$ regulated by Korean Forest Service (2009), so the samples need to be improved its heating value.

Ash content increased with the temperature as $114.54 \%$ at $200^{\circ} \mathrm{C}, 227.97 \%$ at $300{ }^{\circ} \mathrm{C}$, and $264.77 \%$ at $400^{\circ} \mathrm{C}$.

\section{Analysis of process factors influencing heating value in torrefaction}

Figure 2 shows the heating value of each sample in accordance with temperature and holding time. The heating value increased significantly from $200^{\circ} \mathrm{C}$ to $300^{\circ} \mathrm{C}$ but slowly at $400^{\circ} \mathrm{C}$. The heating value increased with holding time at $300^{\circ} \mathrm{C}$, but it did not show distinct tendency at $200^{\circ} \mathrm{C}$ and $400^{\circ} \mathrm{C}$. Rather, the heating value decreased with the holding time. Comparing each heating value, the optimal temperature for torrefaction was $300^{\circ} \mathrm{C}$ and holding time was three hours. The maximum heating value was $4127.22 \mathrm{kcal} / \mathrm{kg}$ at $400^{\circ} \mathrm{C}$ with one hour holding time, and the heating value was 4097.93 $\mathrm{kcal} / \mathrm{kg}$ at $300^{\circ} \mathrm{C}$ with three hours holding time. The color of the sample was dark brown at $200^{\circ} \mathrm{C}$, and it carbonized completely at $300^{\circ} \mathrm{C}$ regardless of holding time as in Figure 4.

Figure 3 shows ash content of the samples according to temperature and holding time. As the temperature rose, the ash content increased. Especially, the ash content was over $35 \%$ at $300^{\circ} \mathrm{C}$ and $40 \%$ at $400^{\circ} \mathrm{C}$. Low ash content is beneficial in using as a fuel for combustion. The ash content should be kept below 30\% in thermal power plants.

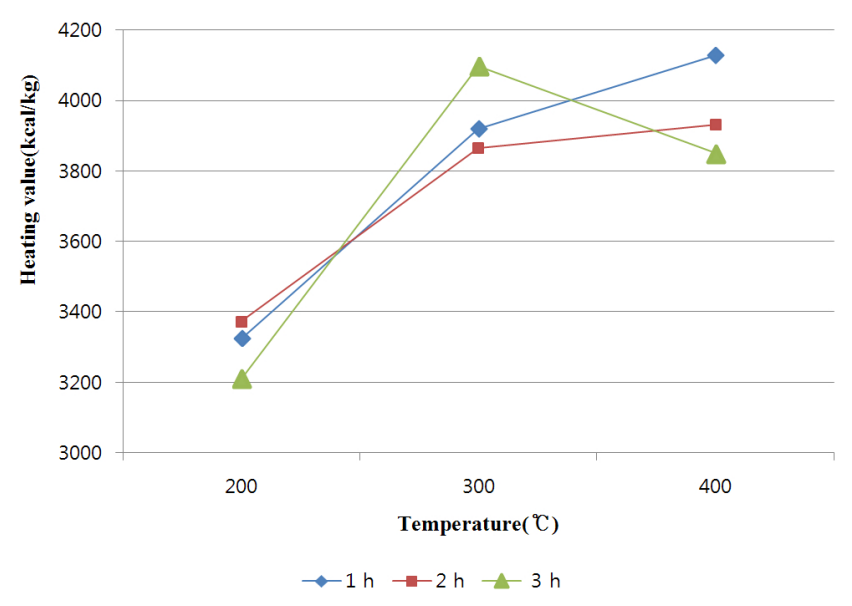

Figure 2. Heating value in accordance with temperature and holding time.

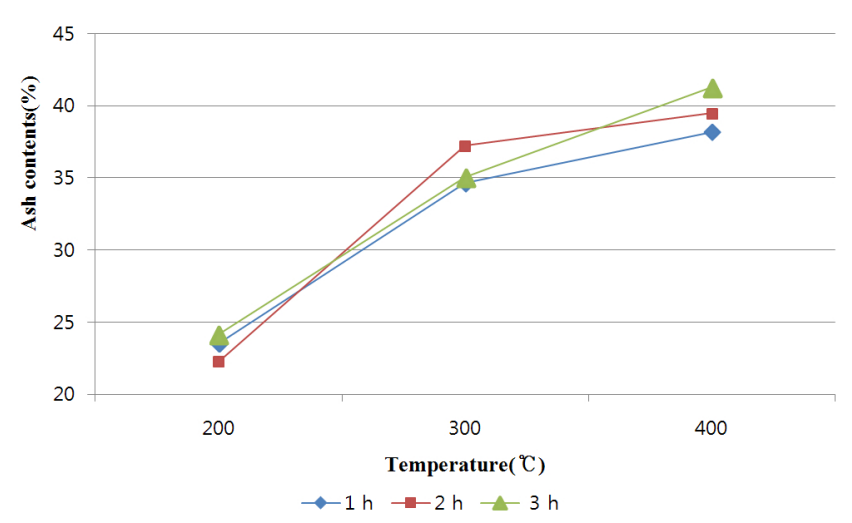

Figure 3. Ash contents according to temperature and holding time.

Even the ash content at $300{ }^{\circ} \mathrm{C}$ was higher than $30 \%$, considering the heating value which is a more important factor in fuel, the optimal temperature and holding time were $300{ }^{\circ} \mathrm{C}$ and three hours, respectively.

\section{Comparison of heating value with washing process}

Two different parts (leaf-stem, and root) of washed and unwashed samples were experimented at $300^{\circ} \mathrm{C}$ with three hours holding time in order to see if there were changes in heating value as in Figure 5. The result showed that the washed plants had high heating values in all 


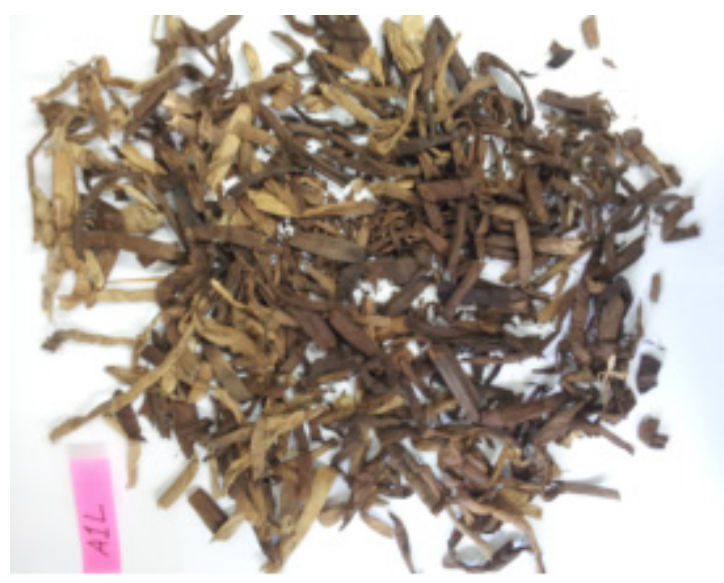

(a)

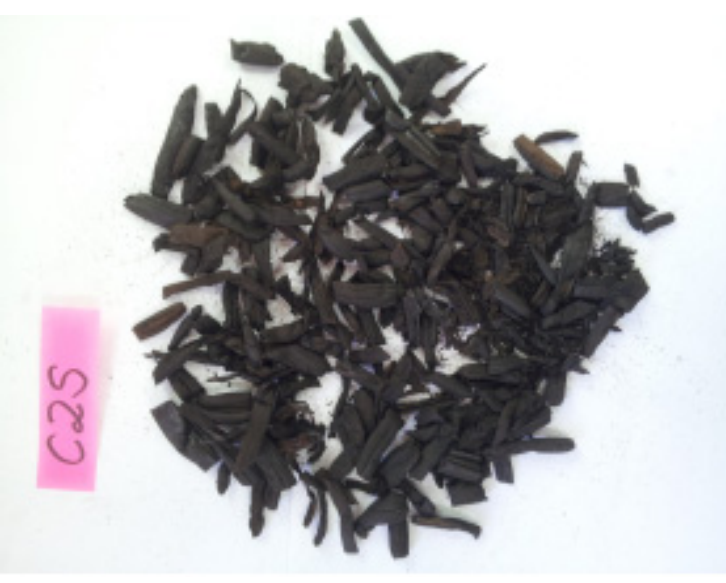

(b)

Figure 4. Color change of samples at different temperature: (a) $200^{\circ} \mathrm{C}$, (b) $300^{\circ} \mathrm{C}$.

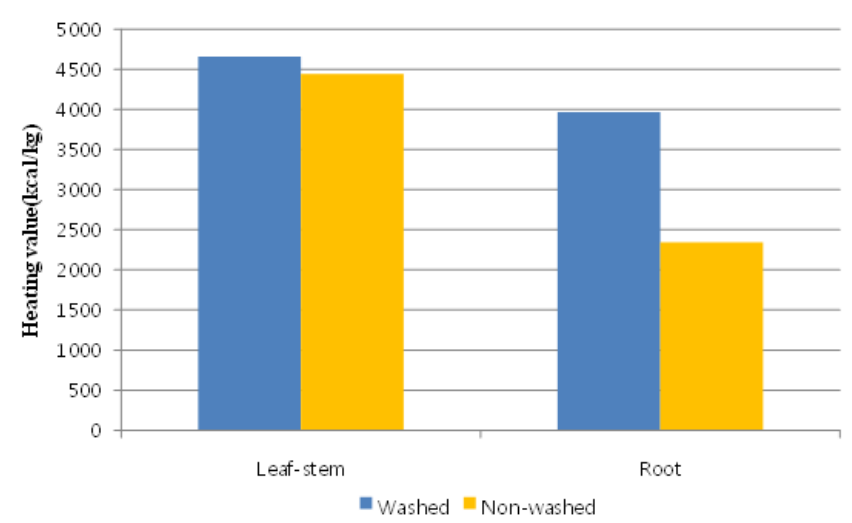

Figure 5. Differences of heating value between washed and unwashed samples $\left(300^{\circ} \mathrm{C}, 3 \mathrm{~h}\right)$.

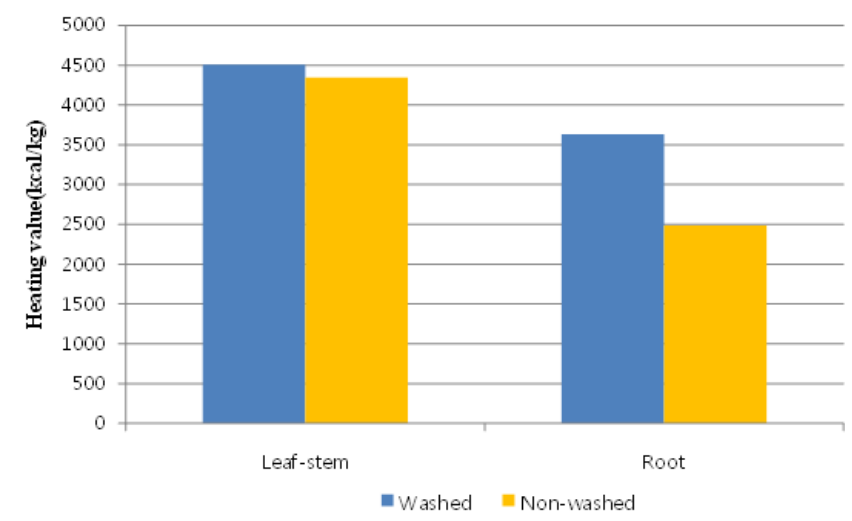

Figure 6. Differences of heating value between washed and unwashed samples $\left(400^{\circ} \mathrm{C}, 1 \mathrm{~h}\right)$.

parts. The difference was double in the roots while it showed similar value in leaves and stems. Figure 6 shows similar results with the experiment at $400^{\circ} \mathrm{C}$ for one hour. Water hyacinth had thick, heavily branched, dark fibrous root system, so the impurities like mud were attached

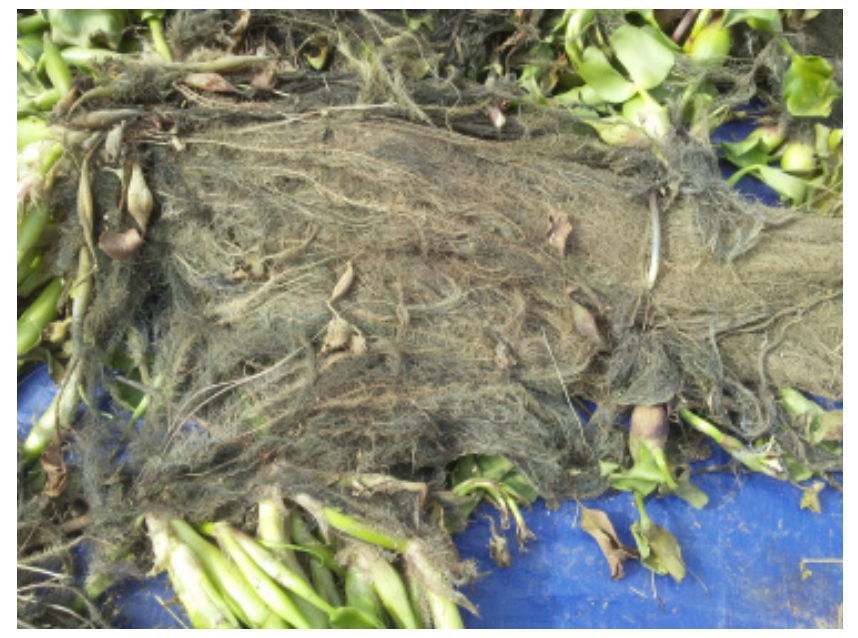

Figure 7. Photography of unwashed root of water hyacinth.

Table 2. Heating value of washed and unwashed samples

\begin{tabular}{ccc}
$\begin{array}{c}\text { Experimental } \\
\text { condition }\end{array}$ & Treatment & $\begin{array}{c}\text { Average heating value } \\
(\mathrm{kcal} / \mathrm{kg})\end{array}$ \\
\hline \multirow{2}{*}{$300^{\circ} \mathrm{C}, 3 \mathrm{~h}$} & Washed & $4310.80 \pm 379.43$ \\
& unwashed & $3395.39 \pm 1150.15$ \\
\hline \multirow{2}{*}{$400^{\circ} \mathrm{C}, 1 \mathrm{~h}$} & Washed & $4067.85 \pm 477.08$ \\
\hline & unwashed & $3414.76 \pm 1015.31$ \\
\hline
\end{tabular}

easily on the roots as in Figure 7. Therefore, the washing process was needed to increase the heating value of the plant.

Table 2 shows the average heating values of washed and unwashed two different parts of samples which had torrefied at $300^{\circ} \mathrm{C}$ for three hours and $400^{\circ} \mathrm{C}$ for one hour respectively. The heating values of washed samples were $4310.80 \mathrm{kcal} / \mathrm{kg}$ and $4067.85 \mathrm{kcal} / \mathrm{kg}$ while unwashed 
ones were $3395.39 \mathrm{kcal} / \mathrm{kg}$ and $3414.76 \mathrm{kcal} / \mathrm{kg}$. The results represented that the washing process increased the heating value by $19 \sim 27 \%$. Especially, the heating value of the sample treated at $300^{\circ} \mathrm{C}$ for three hours was $4310.80 \mathrm{kcal} / \mathrm{kg}$, which was greater than the first class wood pellet of $4300 \mathrm{kcal} / \mathrm{kg}$ regulated by Korean Forest Service. For this reason, the water hyacinth is expected to be an eco-friendly biomass which substitutes for wood.

\section{Conclusions}

Biomass has gained attentions because it can be a possible answer to climate change. Although water hyacinth proliferates rapidly and it is useful for mass production of biomass, it needs to be improved for caloric value to be used for combustible fuel.

This study conducted torrefaction of water hyacinth using small electric heaters and investigated the heating value in terms of heating condition(temperature and holding time). In addition, this study compared the heating values in washed and unwashed samples and suggested the optimal conditions for increasing heating value.

The torrefaction with three different temperature settings and three time settings showed the increase of heating value by $8.18 \sim 30.04 \%$. The comparison of heating values and ash contents in each condition suggested the temperature of $300^{\circ} \mathrm{C}$ with three hours holding time for optimal conditions. The washing process increased the heating value by $19 \sim 27 \%$. Especially, the heating value of the sample treated at $300^{\circ} \mathrm{C}$ for three hours was $4310.80 \mathrm{kcal} / \mathrm{kg}$, which was greater than the first class wood pellet of $4300 \mathrm{kcal} / \mathrm{kg}$ regulated by Korean Forest Service. For this reason, the water hyacinth is expected to be an eco-friendly biomass which substitutes for wood.

\section{Conflict of Interest}

The authors have no conflicting financial or other interests.

\section{References}

Archarya, B., I. Sule and A. Dutta. 2012. A review on advances of torrefaction technologies for biomass processing. Biomass Conv. Bioref. 2:349-369.

Epstein, P. 1998. Weeds bring disease to the east African waterways. Lancet, 351-577.

Gopal, B. 1987. Water Hyacinth. Amsterdam: Elsevier.

Korean Forest Service, 2009. The quality standard of wood pellet. No. 2009-2.

Lee, J. W., Y. H. Kim, S. M. Lee and H. W. Lee. 2012. Torrefaction characteristics of wood chip for the production of high energy density wood pellet. Korean Chem. Eng. Res. 50(2)385-389 (In korean, with English abstract).

Park, Y. S., N. R. Kim, Y. J. Kim, J. H. Koo, J. W. Che, S. I . Nam and J. H. Choi. 2012. Torrefaction of EFB in a fixed bed reactor: influence of process variables on char yield and characteristics. In: Proceedings of the KSWM 2012 Spring Conference. pp. 87-89, Seoul, Korea.

Patel, B., B. Gami and H. Bhimani. 2011. Improved fuel characteristics of cotton stalk, prosopis and sugarcane bagasse through torrefaction. Energy for Sustainable Developmant. 15:372-375.

Pimchuai, A., A. Dutta and P. Basu. 2010. Torrefaction of agriculture residue to enhance combustible properties. Energy Fuels. 24:4638-4645.

Tumuluru, J. S., J. R. Hess, R. D. Boardman, C. T. Wright and T. L. Westover. 2012. Formulation, pretreatment, and densification options to improve biomass specifications for co-firing high percentages with coal. Industrial Biotechnology 8(3):113-132. 